\title{
REVISTAMARACANAN
}

Dossiê

\section{Governos do ultramar ibérico: algumas comparações entre o Estado do Brasil e o Vice-Reino da Nova Espanha}

\author{
Iberian overseas governments: some comparisons between the State of \\ Brazil and the Kingdom of New Spain
}

\author{
Francisco Carlos Cosentino \\ Universidade Federal de Viçosa \\ fcosentino@ufv.br
}

\begin{abstract}
Resumo: Pretendemos, com este trabalho, comparar os governos das conquistas portuguesas e espanholas da América, os governos-gerais/vice-reis do Estado do Brasil e os vice-reinados da América espanhola, destacadamente o da Nova Espanha. Trabalho de História política e administrativa, com interfaces com a História cultural e social, o artigo tem o objetivo de identificar as semelhanças e as diferenças dos poderes de governo e das cerimônias que cercavam a nomeação e a posse desses governantes, particularmente as entradas solenes. Utilizando pesquisa empírica e a historiografia, priorizamos os governantes do Estado do Brasil em contraste com os do Reino da Nova Espanha, reconhecendo diversas semelhanças nos rituais praticados nas duas conquistas e diferenças, destacadamente os papéis diferenciados desempenhados pela Câmara da Bahia e pelo Cabildo do México nas posses desses governos, além da profundidade do poder dos vice-reis espanhóis.
\end{abstract}

Palavras-chave: Governadores-gerais; Vice-reis; Entradas vice-reinais; Estado do Brasil; Vice-Reino da Nova Espanha.

\begin{abstract}
This paper aims to compare the governments of Portuguese America and Spanish America, the general government and viceroys of the State of Brazil and viceroyalties of Spanish America, notably the New Spain. The goal is to identify the similarities and differences of the powers of government and the ceremonies surrounding the appointment and tenure of these rulers, particularly the solemn entries and the government's inauguration. Using empirical research and reports of traditional historians, particularly Mexicans, prioritize the governments the State of Brazil, in contrast to the kingdom of New Spain, recognizing various rituals similarities and differences, notably the different roles played by the Camara da Bahia and the Cabildo of Mexico, beyond the depth of the power of the Spanish viceroys.
\end{abstract}

Keywords: Governors general; Viceroys; State of Brazil; Kingdom of New Spain; Powers of government; Entry and possession.

Artigo recebido para publicação em: Abril de 2016

Artigo aprovado para publicação em: Maio de 2016 
renovação e o incremento dos estudos de História política e administrativa que, nos últimos 20 anos, se faz presente na produção brasileira têm possibilitado a elaboração de múltiplas abordagens sobre a política e o político, particularmente nas suas interfaces com o social e a cultura, despertando interesses diversos, inclusive de comparações, a respeito do modo como se organizou a administração e a vida política das várias partes da América colonial. ${ }^{1}$ Poucos são os estudos a respeito do governo-geral do Estado do Brasil e menos ainda, sobre seus rituais e suas cerimônias políticas. $^{2}$ Em maior número são os trabalhos que tratam dos vice-reis espanhóis, particularmente os das Índias, mas também padecem de certo desprezo e marginalização, como o tratamento que os estudos sobre as instituições e a política receberam das escolas historiográficas predominantes há algumas décadas, ${ }^{3}$ conforme bem nos apresenta Rivero Rodríguez. ${ }^{4}$ A intenção deste artigo é construir algumas conexões e comparações entre os governadores-gerais do Estado do Brasil e os vice-reis da América colonial espanhola, particularmente os do Reino da Nova Espanha. Pretendemos caracterizar e comparar, identificando diferenças e semelhanças, esses dois governantes cimeiros da administração das monarquias ibéricas. Identificaremos e distinguiremos os seus poderes de governo e os aspectos ritualísticos e simbólicos que cercavam as cerimônias de posse e a ação de governo desses governantes do ultramar luso-espanhol.

\section{As monarquias portuguesa e espanhola no Antigo Regime}

As monarquias ibéricas transferiram para as suas conquistas tropicais, guardadas suas particularidades, suas formas e práticas de governo corporativas, jurisdicionais e sinodais, delegando aos seus vice-reis e governadores-gerais essa maneira de governar típica do Antigo Regime.

A natureza da monarquia portuguesa tem sido objeto de estudo, e António Manuel Hespanha ${ }^{5}$ tornou-se uma referência ao questionar argumentos tradicionais e recorrentes, negando o caráter absolutista da monarquia lusa, particularmente nos séculos XVI e XVII, ao constatar que,

[...] o poder real partilhava o espaço político com poderes de maior ou menor hierarquia; o direito legislativo da Coroa era limitado e enquadrado

\footnotetext{
1 Um exemplo conhecido é: ELLIOTT, John H. Imperios del Mundo Atlántico. España y Gran Bretaña en América (1492-1830). Madrid: Taurus, 2006.

2 Ver: SCHWARTZ, Stuart B. Ceremonies of public authority in a colonial capital. The king's processions and the hierarchies of power in seventeenth century Salvador. Anais de História de Além-Mar. Lisboa: CHAM, 2004, v. V, 7-26 e COSENTINO, Francisco Carlos. O ofício e as cerimônias de nomeação e posse para o governo-geral do Estado do Brasil (séculos XVI e XVII). In: Modos de governar. Ideias e práticas políticas no Império português. Séculos XVI a XIX. São Paulo: Alameda Editorial, 2005. p. 137-155.

3 Ver: GIL PUJOL, Xavier. Tiempo de política. Perspectivas historiográficas sobre la Europa Moderna. Barcelona: Publicacions i Edicions Universitat de Barcelona, 2006. p. 75.

${ }^{4}$ RIVERO RODRÍGUEZ, Manuel. La edad de oro de los virreyes. El virreinato en la Monarquía Hispánica durante los siglos XVI y XVII. Madrid: Ediciones Akal, 2011. p. 9-23.

${ }^{5}$ HESPANHA, António Manuel. As vésperas do Leviathan. Coimbra: Almedina, 1994.
} 
pela doutrina jurídica (ius commene) e pelos usos e práticas jurídicos locais; os deveres políticos cediam perante os deveres morais (graça, piedade, misericórdia, gratidão) ou afetivos, decorrentes de laços de amizade, institucionalizados em redes de amigos e de clientes; os oficiais régios gozavam de uma proteção muito alargada dos seus direitos e atribuições, podendo fazê-los valer mesmo em confronto com rei e tendendo, por isso, a minar e expropriar o poder real. ${ }^{6}$

Por isso, nos últimos anos, embalados pela renovação dos estudos da política, particularmente aqueles relacionados ao período moderno, uma série de dicotomias utilizadas para enquadrar e explicar diversas relações - estado-sociedade, corte-país, centro-periferia, revolta-obediência, público-privado ${ }^{-7}$ têm se mostrado insuficientes para compreender a complexa e viva sociedade do Antigo Regime e cedem, ou compartilham lugar, com outras leituras. Por conta disso, recentemente, diversos historiadores têm caracterizado o governo português por meio do conceito de monarquia pluricontinental; ou seja, uma monarquia que era "a cabeça de um desproporcionado império colonial, que fornecia à coroa portuguesa recursos financeiros largamente independentes da pressão tributária sobre o interior do território", 8 isto é, um reino que se sustentava, fundamentalmente, dos proventos oriundos do seu ultramar. ${ }^{9}$ Conforme Nuno Gonçalo Monteiro, sobre essa dependência das rendas das conquistas ultramarinas,

Desde os primórdios da época moderna, na maior parte das conjunturas, era o império que, direta ou indiretamente, sustentava a monarquia, fornecendo em regra, pelo menos, metade dos seus réditos. Através das receitas das alfândegas, que raras vezes representaram menos de um quarto do total e muitas vezes se aproximaram da metade; depois, através dos vários monopólios ligados ao império; e, por fim, por via dos impostos diretos, em particular sobre metais e pedras preciosas. ${ }^{10}$

A monarquia pluricontinental estava intrinsecamente dominada por uma dinâmica sinodal, jurisdicional e corporativa que constituía o regime político desse reino, ou seja, as "instituições que regulam a luta pelo poder e o seu exercício, bem como a prática dos valores

\footnotetext{
${ }^{6}$ HESPANHA, António Manuel. A constituição do Império português. Revisão de alguns enviesamentos correntes. In: O Antigo Regime nos Trópicos: A dinâmica imperial portuguesa (séculos XVI-XVIII). Rio de Janeiro: Civilização Brasileira, 2001. p. 166-167.

7 GIL PUJOL, Xavier. Del estado a los lenguajes políticos, del centro a la periferia: dos décadas de historia política sobre la España de los siglos XVI y XVII. In: Tiempo de política. Perspectivas historiográficas sobre la Europa Moderna..., p. 271.

8 MONTEIRO, Nuno Gonçalo. Monarquia, poderes locais e corpos intermédios no Portugal Moderno (séculos XVII e XVIII). In: Elites e Poder. Entre o Antigo Regime e o Liberalismo, 2. ed. Lisboa: ICS, 2007. p. 24.

9 É importante relativizar essa questão como original de Portugal, pois, como indica Barrientos em obra do século XVII, a América para a Espanha também era fonte de recursos. Ele afirma que "Las Indias occidentales, que sin duda es el fundamento de esta monarquía, como cualquiera provincia de donde viene el dinero, y así lo entendieron los maestros de esa ciencia, de tal manera que es la parte de este imperio con que más cuenta se ha de tener, pues sin dinero quedaríamos sin fuerzas y sin sustancia; y más, estando habituados a los vicios que nos han enseñado las riquezas y la gente que se ha venido tras ellas, y que, faltando oro y plata y las riquezas que vienen de aquellas partes, cesaría también tras esto el comercio y bajarían las rentas reales; que el agua de aquella fuente es la que les da sustancia con que suban y crezcan. (BARRIENTOS, Baltasar Álamos. Discurso político al rey Felipe III al comienzo de su reinado. Barcelona: Anthropos, 1990. p. 13).

10 MONTEIRO, Nuno Gonçalo. A circulação das elites no império dos Bragança (1640-1808): algumas notas. Revista Tempo, n. 27, v. 14, Niterói, jun. 2009, p. 71-72.
} 
que animam tais instituições", ${ }^{11}$ dinâmicas que se estenderam ao ultramar e ordenaram os governos instituídos nas conquistas portuguesas, destacadamente no governo-geral/vice-reino do Estado do Brasil.

Consideramos que a monarquia espanhola, por sua vez, foi uma "monarquia compósita"12 que "estaba formada por reinos e dominios de dos tipos: los adquiridos por herencia o unión dinástica y los adquiridos por conquista". ${ }^{13}$ Rivero Rodríguez, um dos muitos historiadores que dialoga criticamente com essa concepção, destaca a sua natureza "Compuesta de espacios jurisdiccionalmente separados", "naciones que abarcan grupos singularizados y característicos de estados" onde cada parte "constituía un bloque aislado del resto y solo unido al articularse en su representación pública en el teatro de la corte de Madrid"14 por meio dos diversos conselhos territoriais formados para articularem as elites das diversas partes da monarquia. A corte na Espanha dos Austrias foi utilizada para integrar seus diversos reinos e compunha-se de três elementos essenciais: a Casa Real, elemento originário da corte que materializava e legitimava a dinastia reinante; os Conselhos $^{15}$ e tribunais que geriam práticas administrativas racionalizadas com procedimentos informais de decisão e poder e, por fim, os cortesãos, aristocracia que construiu procedimentos de conduta reguladores da sociedade de corte voltados para a obtenção dos benefícios régios. ${ }^{16}$

Dessa forma, a monarquia espanhola não seguiu uma "lógica centralizadora y uniformadora, sino que se basaba en una asociación imprecisa de todos sus territorios, una lógica muy diferente de la del soberano y centralizador estado-nación". ${ }^{17}$ Assim sendo, na Espanha do Antigo Regime, "el poder político se hallaba disperso en una constelación de polos relativamente autónomos, cuya unidad se mantenía, de una manera más simbólica que efectiva" e, na realidade, "obedecía a una lógica en la que cada institución disponía de un poder y jurisdicción propios". Dessa maneira, cabia aos reis "representar a la unidad del cuerpo, y, por el otro, la de mantener la armonía entre todos sus miembros, y garantizar a

\footnotetext{
${ }^{11}$ LEVI, Lucio. Regime Político. In: Dicionário de Política, 5. ed. Brasília: Edunb, 1993. p. 1081. Ver essa discussão em: COSENTINO, Francisco Carlos. Monarquia pluricontinental, o governo sinodal e os governadores-gerais do Estado do Brasil. In: Dinâmica Imperial no Antigo Regime Português. Rio de Janeiro: Mauad X/ ART, 2011. p. 67-82.

12 ELLIOTT, John H. Una Europa de monarquías compuestas. In: España en Europa. Valencia: Universitat de Valencia, 2003. p. 65-91.

13 ELLIOTT, John H. Imperios del Mundo Atlántico..., p. 192.

14 RIVERO RODRÍGUEZ, Manuel. Una monarquía de casas reales y cortes virreinales. In: La monarquía de Felipe III: los reinos, (v. IV). Madrid: Fundación MAPFRE, 2008. p. 34.

15 O "Consejo de Estado [era] el espacio que articulaba a todos estos organismos en conjunto" (MARTÍNEZ MILLÁN, José. La monarquía de Felipe III: corte y reinos. In: La monarquía de Felipe III: los reinos, (v. III). Madrid: Fundación MAPFRE, 2008. p. 51.

16 MARTÍNEZ MILLÁN, José. La corte de la monarquía hispánica. Studia Historia Moderna, 28, 2006. p. 55.

17 CAÑEQUE, Alejandro. Cultura vicerregia y Estado colonial. Una aproximación critica al estudio de la Historia Política de la Nueva España. In: Historia Mexicana, v. LI, n. 1, 2001. p. 11.
} 
cada cual sus derechos y privilegios, o en una palabra, la de hacer justicia". ${ }^{18}$ Ou seja, a monarquia espanhola foi um conglomerado de reinos unidos e ao mesmo tempo desunidos. ${ }^{19}$

No que diz respeito ao jurisdictio, os conselhos criaram um espaço jurisdicional articulado para o conjunto dos reinos "vertebrando la Monarquía alrededor de la administración de la justicia y la defensa de la ley"20 sem, no entanto, ignorar "la existência de constituciones, fueros y leyes separadas, por lo que la unidad imaginaria del consejo se manifestaba en consejos". ${ }^{21}$ Com relação ao gubernatio, a casa régia constituía o núcleo de poder, lugar que acolhia e alojava os privados, cortesãos e ministros, no entanto,

[...] la unidad también era imaginaria pues la casa real era, en realidad, un conjunto de casas [...] cada una tenía su propio modo de servicio, sus propias ordenanzas y etiquetas y unos rasgos peculiares, distintos y singulares, pues el rey era servido por la yuxtaposición de servicios, como jefe particular de cada casa. ${ }^{22}$

Nessa monarquia composta de reinos/nações, o "Rey tiene un doble papel: garantiza tanto la unidad del conjunto como la diversidad de sus componentes". ${ }^{23} \mathrm{O}$ desempenho desses papéis era difícil, pois o rei reside em um dos seus reinos e eventualmente visita os outros. Dessa forma, vive-se na monarquia espanhola uma situação peculiar de "um reino de monarca ausente"24 já que, "el absentismo real era un rasgo ineludible de las monarquias compuestas $^{\prime 25}$. Nesse contexto, a lembrança da plenitude monárquica exigiu expedientes que remediassem a ausência do monarca, condição primeira da conservação dos reinos. A "creación de órganos institucionales nuevos al más alto nivel de gobierno, y a la utilización de prebendas para ganar y conservar la lealtad de las antiguas elites administrativas y políticas"26 constituiu-se em um expediente importante, mas não o único. Também os vice-reis, como representantes de "nuestra Real persona", 27 ao lado dos conselhos e da Corte madrilena "espacio de atracción y de articulación de las élites políticas y sociales de los diversos reinos de la Monarquía Católica"28 - , simbolizavam o rei e desempenhavam um papel fundamental na gestão das várias partes da monarquia.

18 CAÑEQUE, Alejandro. Cultura vicerregia y Estado colonial. Una aproximación critica al estudio de la Historia Política de la Nueva España..., p. 12.

19 Analisando a relação entre Aragão e a monarquia espanhola e reconhecendo as particularidades dos vários reinos unidos em torno do monarca espanhol, ver: FERNÁNDEZ ALBALADEJO, Pablo. LEX REGIA ARAGONENSIUM. Monarquía compuesta e identidad de reinos en el reinado de Felipe III. In: Materia de España. Cultura política e identidad en la España Moderna. Madrid: Marcial Pons, 2007. p. 65-91.

20 RIVERO RODRÍGUEZ, Manuel. La edad de oro de los virreyes..., p. 133.

${ }^{21}$ RIVERO RODRÍGUEZ, Manuel. La edad de oro de los virreyes..., p. 133.

22 Id., ibid., p. 133.

23 BRAVO LIRA, Bernardino. Régimen virreinal. Constantes y variantes de la constitución política en Iberoamérica (siglos XVI-XIX). In: El gobierno del mundo: Virreinatos y Audiencias en la América Hispánica. Cuenca: Universidad de Castilla - La Mancha, 2004. p. 375.

24 BOUZA ÁlVAREZ, Fernando. Portugal no Tempo dos Filipes. Política, Cultura e Representações (15801668). Lisboa: Edições Cosmos, 2000. p. 114.

${ }^{25}$ ELLIOTT, John H. Una Europa de monarquías compuestas..., p. 73.

${ }^{26}$ Id., ibid., p. 73.

${ }_{27}$ Recopilacion de Leyes de los Reynos de las Índias, Tomo I, Libro III, Tít. II. Madrid: Imprenta Nacional del Boletín Oficial del Estado, 1998, 543. A partir de agora, RLRI.

${ }_{28}$ CUNHA, Mafalda Soares da. Títulos portugueses y matrimonios mixtos en la Monarquía Católica. In: Las redes del Imperio. Madrid: Marcial Pons, 2009. p. 208. 
Outras medidas institucionais foram adotadas para minimizar os problemas ocasionados pelas distâncias e muitas dificuldades foram contornadas pela "lealtad a un soberano que a su vez cuidaba con benevolencia de la prosperidad de sus súbditos", ${ }^{29}$ vinculo construído pela concepção que fundamentou a monarquia compósita espanhola, de que "los Reynos se han de regir, y gobernar, como si el Rey que los tiene juntos, lo fuera solamente de cada uno de ellos"; ${ }^{30}$ ou seja, é necessário para compreender a longevidade da monarquia espanhola a "lealtad profunda e instintiva hacia la persona del monarca". ${ }^{31}$ Os soberanos espanhóis construíram o registro de sua autoridade e poder nas mentes e nos corações dos seus súditos e estimularam a elaboração de uma compreensão do mundo que inseria todos como membros e partícipes da vida política, mesmo que, para conseguir se conservar e se perpetuar, "las imágenes reales fueron perfeccionadas, estereotipadas y despojadas de todos los defectos propios de los humanos para convertirlas en un ideal". ${ }^{32}$

O que pretendemos com essa breve caracterização das monarquias portuguesa e espanhola é ressaltar que, se queremos entender a natureza, os rituais e as cerimônias que cercam o exercício do poder pelos governadores-gerais/vice-reis portugueses e pelos vice-reis espanhóis, em toda a sua complexidade e, em consequência disso, a política luso-espanhola adotada no Novo Mundo, devemos ver esses governantes lusitanos e hispânicos como os seus contemporâneos os viam, definindo e constatando a organização e a cultura política da monarquia em Espanha e Portugal durante o Antigo Regime.

\section{Os poderes dos governadores-gerais do Estado do Brasil e dos vice-reis da Nova Espanha}

Os governadores-gerais do Estado do Brasil eram servidores da monarquia portuguesa providos de poderes que Ihes davam, de maneira limitada, dignidade real. Detinham e exerciam jurisdições que, por delegação do monarca português, eram oriundas da transferência de parte das regalias, poderes que eram próprios do ofício régio. ${ }^{33} \mathrm{Em}$ termos práticos, os governadores controlavam as questões de justiça, por isso eram os regedores do Tribunal da Relação, trabalhavam pelo crescimento da Fazenda Real, supervisionando a arrecadação dos tributos, cobrando o pagamento dos direitos régios e autorizando as folhas de pagamento das capitanias, geriam as questões de natureza militar, proviam a serventia de

${ }^{29}$ ELLIOTT, John H. Rey e patria en el Mundo Hispánico. In: España, Europa y el Mundo de Ultramar (1500-1800. Madrid: Taurus, 2010. p. 237.

${ }^{30}$ ELLIOTT, John H. Rey e patria en el Mundo Hispánico..., p. 234.

${ }^{31}$ Id., ibid., p. 237.

32 BRIDIKHINA, Eugenia. Theatrum mundi. Entramados del poder en Charcas colonial. La Paz/Bolívia: IFEA/Plural Editores, 2007. p. 177.

33 "As regalias essenciaes são fazer leys, investir Magistrados, eleger Ministros dignos, \& beneméritos, bater moeda, por tributos, \& a seus tempos publicar guerra, \& fazer pazes" (BLUTEAU, D. Raphael. Vocabulario Portuguez e Latino. Rio de Janeiro: Universidade do Estado do Rio de Janeiro, s/d. CR-ROM, v. VII, p. 193). Entre as regalias que não foram transferidas aos governos do ultramar está a política externa, as relações internacionais e a definição da guerra e da paz, essenciais ao poder e configuração da monarquia que permaneceram nas mãos do rei. E a concessão de mercês, outra regalia importante, quando transferida, o foi, de forma bastante restrita e, muitas vezes, apesar de estabelecida em regimentos, só foi efetivada de maneira bastante localizada. 
cargos e nomeavam os governos das capitanias anexas na ausência da decisão régia. ${ }^{34}$ Atuavam ainda na gestão dos conflitos, procurando arbitrar e negociar as situações de disputa locais e regionais. ${ }^{35}$ Enfim, para exercerem seu papel de principal ofício no Estado do Brasil, certas prerrogativas exclusivas do ofício régio foram transferidas aos governadores-gerais que receberam atribuições que possibilitaram ao monarca português, mesmo que distante, exercer, no Brasil, poderes que não poderiam ser exercidos se, para cá, não tivessem sido enviados esses governantes com a gama de poderes de que dispunham. Os regimentos e as cartas patentes dos governadores-gerais estabeleceram os estilos de funcionamento, a amplitude e os limites da autoridade desses governos em decorrência da delegação dos poderes para eles transferidos. ${ }^{36}$

Por ser o governo-geral um dos postos mais elevados do Império ultramarino português, os seus regimentos e a escolha dos governadores constituíam matéria, por excelência, da alta política, por isso mesmo, percorria os caminhos da consulta do Conselho de Estado e da decisão ou escolha final do monarca. Os regimentos tinham uma importância tão significativa para a ordenação da vida política e administrativa do Estado do Brasil, que a sua elaboração circulava pelos conselhos da sinodal monarquia portuguesa. Assim foi com 0 regimento trazido por Roque da Costa Barreto (1677) que mereceu atenção do Conselho de Estado, como podemos ver nos dois ofícios enviados pelo secretário de Estado ao visconde de Vila Nova de Cerveira convocando-o para "acabar de ver o regimento do Brasil", em 10 de junho de $1676^{37}$ e, para "se acabar de ajustar o regimento do Brasil", um mês depois. A nomeação, a sondagem dos nomes, a formação das preferências e a escolha do governador, eram processos que passavam por consulta e/ou sugestão dos conselheiros e do Conselho de Estado, antes da decisão régia. Assim podemos entender, a manifestação das preferências expressas pelo estribeiro-mor que, em fevereiro de 1705, a pedido do rei, segundo aviso do secretário de Estado, indicou nomes para o governo. Entretanto, como consta do mesmo documento, na sua margem direita, "Nomeou Vossa Majestade Britânica ${ }^{38}$ para este governo a Luís Cesar de Menezes que se achava na Praça de Coura, tendo já feito a do Rio de Janeiro como a de Angola, havendo antes sido Capitão de cavalos e de mar e guerra". ${ }^{39}$

\footnotetext{
34 COSENTINO, Francisco Carlos. Hierarquia política e poder no Estado do Brasil: o governo-geral e as capitanias, 1654-1681. Topoi. Revista de História, Rio de Janeiro, v. 16, n. 31, jul./dez. 2015. p. 515543.

35 Ver o papel desempenhado por Jerônimo de Ataíde, conde de Atouguia na construção de um acordo que criou as condições para resolver os conflitos envolvendo os Pires e os Camargos na vila e na Câmara de São Paulo em meados do século XVII (TAUNAY, Alfredo Maria Adriano d'Escragnolle. História da Cidade de São Paulo. São Paulo: Poeteiro Editor Digital, 2014; e, FRANCO, Francisco de Assis Carvalho. Os capitães-mores vicentinos. São Paulo: Separata da Revista do Arquivo, n. LXV, 1940).

36 Sobre os regimentos, ver: COSENTINO, Francisco Carlos. Governadores gerais do Estado do Brasil (séculos XVI-XVII): ofício, regimentos, governação e trajetórias. São Paulo: Annablume/FAPEMIG, 2009. p. 245-303.

37 Biblioteca da Ajuda. 52 - IX - 9, fol. 52

38 Trata-se de D. Catarina de Bragança, viúva de Carlos II, rei da Inglaterra, que foi regente de Portugal, quando da doença de D. Pedro I, seu irmão.

${ }^{39}$ BNL - Coleção Pombalina, cód. 230. Votos e papéis pertencentes ao Conselho de Estado, fol. 1-1v.
} 
A patente de Tomé de Sousa, que funda esse governo nas terras do Brasil, é esclarecedora do que se estava criando na América lusa em termos políticos e administrativos. Segundo a carta patente,

[...] quanto cumpre a serviço de Deus e meu conservar e enobrecer as capitanias e povoações que tenho nas minhas terras do Brasil ordenei ora mandar fazer uma fortaleza e povoação grande e forte na Bahia de Todos os Santos por ser para isso o mais conveniente lugar que há nas ditas terras do Brasil para dai se dar favor e ajuda as outras povoações e se ministrar justiça e prover nas cousas que cumprem a meu serviço e aos negócios de minha fazenda e a bem das partes. ${ }^{40}$

Estão apresentadas, nessa passagem do provimento de Tomé de Sousa, as finalidades do governo-geral e suas funções: estimular a continuidade da colonização auxiliando as capitanias, garantir a justiça, cuidar da fazenda e garantir a paz, o que envolve defesa. Esses eram os poderes dos governadores-gerais que, por ser um ofício delegado, sua nomeação resultava da confiança do monarca e exigia, por isso mesmo, como contrapartida, fidelidade.

A organização dos vice-reinados espanhóis ${ }^{41}$ na América deve-se por um lado a "la consolidada práctica que a estas alturas tenía la monarquía española de utilizar virreyes para el gobierno de amplios distritos territoriales peninsulares y mediterráneos" ${ }^{\prime 42}$ e por outro, "asume también la experiencia e peculiaridad indiana". ${ }^{43}$ Reconhecia-se dessa maneira a importância do antigo reino asteca, a amplitude e complexidade que o povoamento dessa região havia adquirido e, além disso, ampliava-se a retomada das atribuições governativas e militares inicialmente concedidas aos conquistadores, iniciada com a formação das Audiências e completada com o vice-reinado. Assim, o ofício de vice-rei foi à síntese que associou a experiência da prática vice-reinal da Espanha com as peculiaridades da América hispânica, particularmente da Nova Espanha.

Criados em 1535 com a nomeação de Antonio de Mendonza para o Reino da Nova Espanha, os vice-reis tiveram seus poderes definidos quando Carlos V, em 1542, regulamentou o vice-reinado nas terras espanholas da América. ${ }^{44}$ Essa lei estabelecia que os

Reynos de el Perú y Nueva España sean regidos y gobernados por Vireyes, que representen nuestra Real persona, y tengan el gobierno supeior, hagan y administren justicia igualmente á todos nuetros súbditos y vasallos, y entiendan en todo lo que conviene al sosiego, quietud,

\footnotetext{
${ }^{40}$ ANTT - Chancelaria de D. João III - Livro 55 fol. 120-120v - Carta patente de Governador Geral de Tomé de Sousa.

41 "[...] [...] el virreinato se concibió entre 1519 y 1520 como una solución para la ausencia del rey inspirándose en parte en la experiencia aragonesa" (RIVERO RODRÍGUEZ, Manuel. La edad de oro de los virreyes..., p. 68).

42 BERMÚDEZ, Agustín. La implantación del régimen virreinal en Indias. In: El gobierno del mundo: Virreinatos y Audiencias en la América Hispánica. Cuenca: Universidad de Castilla - La Mancha, 2004. p. 282.

${ }^{43}$ Agustín Bermúdez. La implantación del régimen virreinal..., p. 282.

44 "Ley Primera. Que los Reinos del Perú y Nueva España sean regidos y gobernados por Virreyes. El Emperador D. Carlos en Barcelona, 20 de Noviembre de 1542" (RLRI, Tomo I, Libro III, Título 30, p. 543).
} 
ennoblecimiento y pacificación de aquellas Provincias, como por leyes de este título y Recopilacion se dispone y ordena. ${ }^{45}$

Dessa maneira, eram os vice-reis espanhóis da América os representantes de "nuestra Real persona", 46 o que deu a eles, ainda, "el gobierno superior, hagan y administren justicia igualmente a todos nuestros súbditos y vassalos, y entiendan en todo lo que conviene al sosiego, quietud, ennoblecimiento y pacificación de aquellas Provincias" ${ }^{47}$ Segundo Solórzano Pereyra, "convino que nuestros poderosos Reyes pusiesen estas imágenes suyas que viva y eficazmente los representasen". ${ }^{48}$ Ainda, conforme o mesmo autor, os vice-reis, "tienen y ejercen el mismo poder, mano y jurisdicción que el rey los nombra y ésa no tanto delegada, como ordinaria", ${ }^{49}$ pois "donde quiera que se da imagen de otro, allí se da verdadera representación de aquel cuya imagen se trae o representa". ${ }^{50}$ Por isso mesmo, os vice-reis como representação da pessoa régia "en Cataluña y otras partes los llaman 'alter Nos' por esta omnímoda semejanza o representación". ${ }^{51}$

A monarquia portuguesa não elaborou, durante o Antigo Regime, uma legislação específica para suas conquistas ultramarinas, como fez a espanhola por meio da chamada "Recopilacion de Leyes de los Reynos de las Índias", de 1680. Entretanto, os governos ultramarinos lusos eram instruídos por regimentos que definiam as diversas atribuições dos seus governadores, inclusive o governador-geral do Estado do Brasil. Esses regimentos, que ao longo das conjunturas vividas pela monarquia portuguesa e suas conquistas ultramarinas, foram sendo alterados, ganharam sua forma definitiva em 1677, quando foi enviado ao Brasil Roque da Costa Barreto. ${ }^{52}$ Diversos governadores também trouxeram instruções que, na maioria das vezes, reafirmavam as orientações do seu regimento, fundamento da ordenação desse governo. Os vice-reis da América espanhola tinham nas leis específicas do ultramar castelhano a definição de seus poderes. Ao lado disso, aos vice-reis eram dadas Instrucciones ${ }^{53}$ que, de maneira muito semelhante aos regimentos do governo-geral do Estado do Brasil, instruíam os vice-reis quanto à relação com os outros poderes, inclusive a Igreja, fonte recorrente de disputas, quanto ao provimento em serventia dos diversos cargos políticos e administrativos e, particularmente, como elemento original das instruções espanholas, a

\footnotetext{
45 RLRI, Tomo I, Libro III, Título 30, p. 543.

${ }^{46}$ RLRI, Tomo I, Libro III, Título 30, p. 543.

47 RLRI, Tomo I, Libro III, Título 20, p. 543.

48 PEREYRA, Juan Solórzano. Política Indiana. Tomo III. Madrid: Fundación José Antonio de Castro, 1996. p. 2118.

49 PEREYRA, Juan Solórzano. Política Indiana..., p. 2119.

50 Id., ibid., p. 2120.

${ }^{51}$ Id., ibid., p. 2119.

52 Sobre os regimentos do governo-geral do Estado do Brasil ver: COSENTINO, Francisco Carlos. Governadores gerais do Estado do Brasil (séculos XVI-XVII)..., p. 245-303. Sem tratar dos regimentos, mas, analisando o Estado do Maranhão e Grão-Pará, ver: SANTOS, Fabiano Vilaça. O governo das conquistas do norte: trajetórias administrativas no Estado do Grão-Pará e Maranhão (1751-1780). São Paulo: Annablume, 2011.

53 Ver a esse respeito: RUBIO MANÉ, José Ignacio. El Virreinato I. Origenes y jurisdicciones, y dinámica social de los virreyes. Mexico: Fondo de Cultura Económica, 1992; TORRE VILLAR, Ernesto. Instrucciones y memorias de los Virreyes Novohispanos. Mexico: Editorial Porruá, 1991; e HANKE, Lewis. Los virreyes españoles en América durante el gobierno de la Casa de Austria, 5 v. Madrid: Ediciones Atlas, $1976-78$.
} 
questão dos indígenas. ${ }^{54}$ Outra especificidade da administração espanhola foram as Memórias ${ }^{55}$ que os vice-reis que deixavam o cargo eram obrigados a elaborar para seus sucessores, construindo uma cultura administrativa importante para o exercício dos governos na América hispânica ao longo do tempo. Fazia-se também, o Juízo de Residência que auditava, sobre vários aspectos, os governos que terminavam. Essa prática, nas conquistas portuguesas, só foi empregada episodicamente durante a União Ibérica. ${ }^{56}$

\section{Nomeação e juramento de fidelidade dos governantes das conquistas ibéricas da América}

Por muito tempo, os rituais e as cerimônias foram desqualificados e não eram compreendidos como objeto de estudo da história e do poder, o que minimizou o seu papel enquanto fonte de compreensão da política. ${ }^{57}$ No nosso entendimento, essas atividades são parte integrante da política e do exercício do poder, destacadamente durante o Antigo Regime, ${ }^{58}$ onde a vida cotidiana, a vida social e política estavam impregnadas de elementos que trabalhavam para a construção da ordem e da coesão de uma sociedade, pois, os rituais,

[...] alientan y mantienen la solidaridad de la comunidad: "lanzando el mismo grito, pronunciando la misma palabra o realizando el mismo gesto hacia algún objeto, las gentes se armonizan y se sienten en armonía". En este sentido, los rituales públicos se convierten en la vía necesaria para lograr la cohesión del grupo. ${ }^{59}$

Apesar de os rituais e as cerimônias não serem mais compreendidos apenas como fenômenos relacionados a práticas de natureza religiosa, é preciso constatar a influência religiosa que neles existiu nos países ibéricos, onde era significativo o domínio dos paradigmas da escolástica. Dessa maneira, na monarquia espanhola, a maioria dos seus rituais tinha sua

54 Os diversos regimentos analisados apresentam instruções coerentes com a realidade a que se destinam. Exemplo dessa situação foi o regimento de André Vidal de Negreiros para o governo-geral do Estado do Maranhão e Grão-Pará com seus diversos parágrafos direcionados para a questão indígena, particularmente aqueles relacionados "A repartição do serviço dos ditos índios" que segundo o regimento "será feita por dois árbitros, um dos mesmos seus Párocos, e outro nomeado pelas Câmaras, nas partes aonde se fizerem as repartições". São 19 parágrafos de um total de 58 em que são tratados temas relacionados com os indígenas, da repartição do seu trabalho, das entradas de conversão, do trabalho e do controle do governador-geral sobre a ação missionária e outras questões correlatas.

55 Segundo Rivero Rodríguez, as primeiras Memórias foram pedidas em 1580 por Felipe II ao vice-rei do Peru, Francisco de Toledo (1569-1581), com cópias para o Conselho das Índias, para ser entregue a seu sucessor, prática que teve continuidade para os seguintes e para os outros vice-reinados espanhóis, inclusive europeus. A elaboração das Memórias nem sempre era bem aceita pelos vice-reis e, muitas vezes, "hubo que amenazar con no pagar a los Virreyes subordinados a este Consejo el sueldo del último año sino es que conste se han embiado las relaciones"" (RIVERO RODRÍGUEZ, Manuel. La edad de oro de los virreyes..., p. 204).

${ }^{56}$ COSENTINO, Francisco Carlos. Mundo português e mundo ibérico. In: O Brasil Colonial, 1580-1720, v. 2. Rio de Janeiro: Civilização Brasileira, 2014. p. 107-167.

57 Ver: COSENTINO, Francisco Carlos. Título régio, rituais e cerimônias políticas no Antigo Regime. Império e governo no reino e no ultramar luso. Revista Ultramares, n. 8, v. 1. Maceió, ago./dez. 2015. p. $10-28$.

58 "[...] las ceremonias rituales no son una simple operación de cosmética del poder, o su máscara, sino, antes bien, parte integral del poder y de la política" (CAÑEQUE, Alejandro. De sillas y almohadones o de la naturaleza ritual del poder en la Nueva España..., p. 610).

59 MUIR, Edward. Fiesta y rito en la Europa Moderna. Madrid: Editorial Complutense, 2001. p. XV. 
origem no vocabulário ritual da Igreja Católica. ${ }^{60} \mathrm{O}$ mesmo ocorreu em Portugal e na América lusa, que, como ressaltou Stuart B. Schwartz sobre as procissões, indicou que elas foram uma maneira bem-sucedida de transmitir mensagens da Igreja e do poder político. ${ }^{61}$

Pretendemos, nas próximas páginas deste artigo, explorar as cerimônias e os rituais que faziam parte da nomeação, do juramento de fidelidade ao monarca e das entradas para tomada de posse dos governadores-gerais/vice-reis lusitanos e dos vice-reis castelhanos. Entendemos essas práticas como componentes relevantes da política e da dinâmica do poder no Antigo Regime, compreendendo, como faz Rivero Rodríguez, que, todos "os actos de la vida, de la sociedad y del gobierno se desenvolvían en un espacio ritualizado, todo se sancionaba o incorporaba en la realidad mediante un rito, una fiesta, un espectáculo o una ceremonia", ${ }^{62}$ já que, no Antigo Regime, essas eram práticas que cimentavam a autoridade, a adesão, o compromisso, a fidelidade e a lealdade dos súditos à monarquia e ao rei, e "os mecanismos de controlo não eram, frequentemente, visíveis e explícitos; não tinham lugares, centros ou nomes marcados; nem sequer, frequentemente, eram tidos como tais". ${ }^{63}$ Assim, os rituais e as cerimônias exerceram um papel destacado na governação dos reinos ibéricos, estendendo-se também para as conquistas ultramarinas, ${ }^{64}$ pois "Tales ritos eran 'constituyentes' en el sentido de que su representación" ${ }^{65}$ e criavam estruturas rituais para as monarquias "en una época previa a la de las constituciones escritas: "El estado es invisible; hay que personificarlo antes de poder verlo; que simbolizarlo antes de poder amarlo; que imaginarlo antes de poder concebirlo". ${ }^{66}$ Afinal, como os monarcas estavam distantes de suas conquistas ultramarinas, a necessidade de construir cotidianamente a lembrança do seu poder exigiu expedientes que remediassem a sua ausência e sistematicamente lembrassem a sua existência, condição primeira da sua conservação.

Os governadores-gerais/vice-reis do Estado do Brasil, depois de providos por carta patente régia, prestavam juramento de fidelidade ao rei através do preito \& menagem. Essa cerimônia reproduzia um costume ritual de natureza medieval e selava um compromisso simbolizando a delegação dos poderes e dando legitimidade ao exercício do cargo. ${ }^{67}$ Nos dois

\footnotetext{
60 "[...] puesto que la teología católica de la época sostenía que el ritual posee la capacidad de hacer existir, de hacer presente (la Hostia consagrada no representa el cuerpo de Cristo, es el Cuerpo de Cristo), no debería sorprendernos, por tanto, que uno de los principios rectores de la Monarquía Hispánica, la monarquía católica por antonomasia, fuera la idea de que el poder se hacia presente por medio de representaciones ceremoniales" (CAÑEQUE, Alejandro. De sillas y almohadones o de la naturaleza ritual del poder en la Nueva España..., p. 613).

${ }^{61}$ SCHWARTZ, Stuart B. Ceremonies of public authority in a colonial capital. The king's processions and the hierarchies of power in seventeenth century Salvador. Anais de História do Além mar, v. V, 2004. p. 7-26.

62 RIVERO RODRÍGUEZ, Manuel. La edad de oro de los virreyes..., p. 181.

${ }^{63}$ HESPANHA, António Manuel. A monarquia: a legislação e os agentes. In: História da vida privada em Portugal. Maia/Portugal: Círculo de Leitores, 2011. p. 12.

${ }^{64}$ CANNEQUE, Alejandro. De sillas y almohadones o de la naturaleza ritual del poder en la Nueva España..., p. 612.

65 MUIR, Edward. Fiesta y rito en la Europa Moderna..., p. 289. A citação de Muir reproduz WALZER, Michael. On the Role of Symbolism in Political Thought, Political Science Quarterly 82, 1967. p. 194.

${ }^{66}$ Id., ibid., p. 289.

67 COSENTINO, Francisco Carlos. O ofício e as cerimônias de nomeação e posse para o governo-geral do Estado do Brasil..., p. 137-155.
} 
documentos vinculados à nomeação e à regulamentação desse cargo - as cartas patentes e os regimentos -, encontramos instruções que tratam e orientam a provisão e a investidura do ofício de governador. As cerimônias de juramento e de preito \& menagem estabeleciam relações pessoais entre o rei e os seus servidores e eram necessárias devido à ordem jurisdicional vigente. Elas agiam também para dar coerência e unidade à ação governativa, conferindo consistência e legitimidade às práticas delegativas de poder, pois a natureza dos ofícios superiores de governo, que eram resultado da confiança, do respeito e da estima do rei, apenas exigiam fidelidade de quem o recebia.

Apenas o juramento, entretanto, não dava aos nomeados a posse do cargo. $O$ governador em exercício ainda estava comprometido com o monarca por esse mesmo compromisso. Dessa forma, a posse acontecia quando da chegada à Bahia e, mais tarde, no final dos Setecentos, ao Rio de Janeiro. O novo governador-geral/vice-rei entregava ao que estava deixando o cargo a carta com a dispensa régia formal dos compromissos assumidos por ele quando de sua nomeação. ${ }^{68} \mathrm{Na}$ carta do rei ao conde das Galveias, de 28 de outubro de 1749, o monarca o desobriga do preito \& menagem feito em favor de D. Luiz Peregrino de Ataíde, conde de Atouguia (1749-1755). Conforme o documento,

Ao Conde de Atouguia fuy servido fazer mercê do Cargo de V. Rey e Capitão General como vos constará da Carta Patente que dele Ihe mandei passar. Encomendo-vos que na forma costumada [lhe] deis posse do Governo que estais exercitando com as cerimonias, que em semelhantes atos se costumam, de que se fará assento, em que ambos assinareis, e havendo-Ihe dado a dita posse, e as noticias que julgardes por convenientes a meu serviço, vos hei por desobrigado da homenagem, que pelo dito Governo me fizestes. ${ }^{69}$

Também os vice-reis da América espanhola prestavam juramento ao rei. De acordo com Solórzano Pereyra, se já não tivesse sido feito, poderia ser realizado quando da chegada à América. Segundo ele, "se requiere que haya jurado y jure usar y administrar bien y fielmente el oficio, si ya no es que traiga hecho este juramento desde España en manos del rey que le

\footnotetext{
68 Não existem diferenças formais ou de conteúdo entre as cartas patentes dos governadores-gerais e dos vice-reis nomeados durante o século XVIII. Exceto pela distinção do título, importantíssimo, numa sociedade de Antigo Regime, entretanto, do ponto de vista dos poderes, nada se alterou entre governadores-gerais e vice-reis. As exceções ficam por conta do marquês de Montalvão e do conde de Óbidos. Montalvão foi enviado ao Estado do Brasil como vice-rei, em 1640, e a historiografia tem repetido que ele veio com esse título para negociar com Maurício de Nassau com a mesma estatura. Entendemos diferentemente e acreditamos que o governo filipino pretendia instituir essa forma de governo. Na carta patente de Montalvão está dito, "[...] [...] e tudo o que por ele de minha parte vos for mandado cumprais e façais inteiramente com aquela diligencia e cuidado que de vos confio como fizeres se por mim em pessoa vos fosse mandado" (ANTT - Chancelaria Felipe III. Livro 28, fol. 297). Essa era a fórmula empregada para os vice-reinados espanhóis: "nuestra Real persona" (RLRI, Tomo I, Libro III, Tít. II. Madrid: INBOE, 1998, p. 543). Os mesmos termos empregados na carta patente do marquês de Montalvão, aparecem na carta patente do conde de Óbidos, enviado como vice-rei em 1663 (BNRJ - SM. $1,2,5)$. Óbidos foi enviado como vice-rei, pois já o havia sido no Estado da Índia e, segundo as regras da sociedade de corte portuguesa de sua época, vir com outro cargo menoR, como o de governador, seria humilhante e ofensivo.

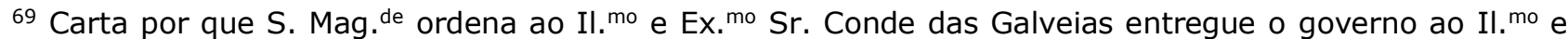
Ex. ${ }^{\text {mo }} \mathrm{Sr}$. Conde de Atouguia. BNRJ - Seção de Manuscritos, 1, 2, 5.
} 
proveyó para el, o de su Consejo Supremo". ${ }^{70}$ Para Covarrubias, o "juramento solene, en favor del rey, o señor"71 é denominado homenagem que, nesse dicionário do século XVII, aparece como "pleyto omenage" da qual decorre a palavra pleitesía que é a "fidelidad de lo que un hijodalgo ha prometido solemnemente". ${ }^{72}$ Na Recopilación, uma fórmula geral e a necessidade do juramento "antes de entrar en sus oficios" estão indicadas. ${ }^{73}$

É importante destacar que a nomeação dos ofícios ${ }^{74}$ nas monarquias ibéricas, particularmente os cargos com a distinção de ministro, ${ }^{75}$ como os governantes ultramarinos que estamos analisando, inseria-se na lógica da remuneração de serviços e constituía-se em mercê régia. $E$, por não termos, nesse momento, uma ligação funcional entre o monarca e os seus servidores, eram as "relações de serviço modeladas pelo imaginário da vassalagem e pela amizade clientelar". ${ }^{76}$ Assim, o provimento de um governador-geral/vice-rei para o Estado do Brasil ou o nombramiento de um vice-rei da América espanhola77 respeitava os critérios de confiança e qualidade social transformados em mercê régia, como podemos ver na carta patente de D. Marcos de Noronha, conde dos Arcos (1755-1760) que dizia,

[...] tendo consideração às qualidades, merecimentos e serviços que concorrem na pessoa do Conde dos Arcos, D. Marcos de Noronha [...] e a que dará inteira satisfação a tudo o que lhe for encarregado conforme quem é e a muita confiança que faço da sua Pessoa, e por folgar de the fazer em tudo honra, acrescentamento e mercê, hei por bem de nomear por vice-rei e Capitão General de mar e terra do Estado do Brasil. ${ }^{78}$

Para a comparação que estamos fazendo são representativas as formas de tratamento utilizadas para os governadores-gerais e os vice-reis. Como já indicamos em outros trabalhos, os ofícios superiores da administração ultramarina portuguesa - governadores-gerais da América lusa, vice-reis e governadores das partes da Índia ${ }^{79}$ - deveriam ser tratados por Senhoria, expressão distintiva que simbolizava status elevado, pois era esse o tratamento que

\footnotetext{
70 PEREYRA, Juan Solórzano. Política Indiana..., p. 2173.

${ }^{71}$ COVARRUBIAS, Sebastián de. Tesoro de la Lengua Castellana o española..., p. 837.

${ }^{72}$ Id., ibid., p. 874.

73 RLRI, Tomo II, Libro VIII, Tít. IIII, p. 428.
}

74 O ofício é um "Cargo publico que dá authoridade para mandar, ou executar coisas concernentes ao governo, como são officios de justiça, fazenda, milícia \& c." (D. Raphael Bluteau. Vocabulario Portuguez e Latino...,v. VI, p. 47-48). Covarrubias afinado com a divisão corporativa da sociedade ressalta que ofício "sinifica la ocupación que cada uno tiene en su estado" (Sebastián de Covarrubias. Op. cit., p. 835).

75 Ministro era "Aquele de quem o Principe fia a administração de cousas concernentes ao governo" (D. Raphael Bluteau. Vocabulario Portuguez e Latino..., v. V, p. 499).

76 CARDIM, Pedro. Centralização Política e Estado na Recente Historiografia sobre o Portugal do Antigo Regime. In: NAÇÃO E DEFESA, n. 87. Lisboa: Instituto de Defesa Nacional, 1998. p. 146.

77 Como exemplo, na América espanhola, temos o nombramiento de Juan de Mendoza y Luna, marquês de Montesclaros (1603-1607) onde o monarca afirmava: "[...] Conviene proveer en su lugar persona que los sirva de las partes y qua le vades q' para tan grande ministerio se requiere y teniendo satisfacion de que estas concurren en Vos don Joan de mendoza y luna Marques de Montesclaros mi asistente de la ciudad de Sevilla y del celo y cuidado con que me haveis servido y que lo continuareis ha delante [...]" (Archivo General de Indias - Patronato, 293, n. 25, r. 56. Disponível em: http://pares.mcu.es/. Acesso em: 21/04/2010).

78 BNRJ - Seção de Manuscritos, 1, 2, 5.

79 "Que nas partes da Índia escrevão o fallem por Senhoria ao Vice-rey, ou Governador dellas todas as pessoas que la andarem" Ver BNRJ - SM. Regimentos e Estilos da Casa Real e Secretaria de Estado. I, $14,3,21$. 
"Em Portugal se falla aos Condes, \& a algus Ministros". ${ }^{80}$ Essa expressão, nos permitiu constatar que o uso apropriado das formas de tratamento são elementos definidores das hierarquias numa sociedade de corte $^{81}$ em que, as posições sociais devem ser bem conservadas. Dessa maneira, o emprego do tratamento de senhoria, reputava ao detentor do ofício de governo prestígio assemelhado ao de um conde - um nobre com título - ou funcionário de grau elevado. Os vice-reis da Nova Espanha recebiam o mesmo tratamento dispensado aos governadores do Estado do Brasil. A Recopilacion de Leyes de los Reynos de las Índias estabelecia que "á los Vireyes se les llame Señoría por escrito y de palabra al tiempo que nos sirvieren en estos cargos". ${ }^{82}$ Segundo Covarrubias, o sentido do termo senhoria na Espanha dos Seiscentos era semelhante ao seu significado em Portugal; para ele, señoría, "Es la cortesía que se da a los señores titulados", ${ }^{83}$ ou seja, também na Espanha, a expressão tem uma natureza social distintiva: aqueles que o recebiam ocupavam uma posição hierarquicamente superior.

\section{Entrada e posse dos governadores e vice-reis no ultramar ibero-americano}

A entrada e a posse dos governantes europeus nas conquistas do ultramar americano se constituíram em momentos cerimoniais muito importantes, sobre vários aspectos, e guardavam entre si, apesar das significativas diferenças políticas e sociais existentes entre as monarquias europeias, semelhanças muito expressivas. ${ }^{84}$

Por um lado, a chegada e a posse desses governantes constituíam um momento de "reconocimiento de la autoridad de los gobernantes por los gobernados", 85 muitas vezes, "[...] el primer contacto físico entre unos y otros" 86 e, por isso mesmo, era cercado de um cerimonial que se repetia conforme as tradições. Por outro lado, era marcado pelo rigor dos seus estilos, pois, guardadas as diferenças entre eles, eram sempre a representação do poder dos monarcas, ausentes e distantes, mas presentes nos diversos símbolos de sua majestade.

Como veremos a seguir, com diferentes profundidades, particularizando e detalhando as entradas e posses dos governantes portugueses no Estado do Brasil em contraste com as dos vice-reis espanhóis, as entradas dos governantes europeus nas regiões que iam governar, resgataram, à semelhança das entradas régias na Europa, os elementos romanos, medievais e

80 BLUTEAU, D. Raphael. Vocabulario Portuguez..., v. VII, p. 582.

81 ELIAS, Norbert. A Sociedade de Corte. Rio de Janeiro: Jorge Zahar Editores, 2001.

82 RLRI, Tomo I, Libro III, Tít. XV, p. 643.

83 COVARRUBIAS, Sebastián de. Op. cit., p. 934.

${ }^{84}$ Existem estudos que, com diferentes abordagens, ênfases e intenções, analisam entradas régias e eclesiásticas, entre eles citamos: CARDIM, Pedro. Entradas solenes, rituais comunitários e festas políticas, Portugal e Brasil, séculos XVI e XVII. In: Festa. Cultura e sociabilidade na América Portuguesa, v. I. São Paulo: Imprensa Oficial/Hucitec/EDUSP/FAPESP, 2001. p. 97-124; e PAIVA, José Pedro. Etiqueta e cerimônias públicas na esfera da Igreja (séculos XVII-XVIII). In: Festa. Cultura e sociabilidade na América Portuguesa, v. I..., p. 75-94. Sobre a presença dos Filipes em Portugal, ver: MEGIANI, Ana Paula Torres. O rei ausente: festa e cultura política nas visitas dos Filipes a Portugal (1581-1619). São Paulo: Alameda, 2004. p. 83-164. Ver ainda: Francisco Carlos Cosentino. Título régio, rituais e cerimônias políticas no Antigo Regime...., p. 10-28.

85 RIVERO RODRÍGUEZ, Manuel. La edad de oro de los virreyes..., p. 182.

${ }^{86}$ Id., ibid., p. 182. 
modernos das chamadas entradas triunfais. A cerimônia de entrada triunfal era uma das festividades mais importantes do mundo romano e o "honor más grande que un ciudadano romano podía disfrutar", ${ }^{87}$ por isso, as diversas exigências e o controle do Senado sobre ela. ${ }^{88}$ O triumphus era um grandioso e majestoso desfile que ia do Campo de Marte ao templo de Júpiter "en medio de una Roma repleta de población que vitoreaba a sus héroes y lucia totalmente engalanada con adornos, colgaduras, guirnaldas y arcos". ${ }^{89}$ As entradas medievais começavam fora da cidade onde as autoridades civis e eclesiásticas urbanas, os cidadãos e as corporações, recebiam o monarca e, em frente à porta das muralhas, "el rey hará el juramento, convertido en el lacto central de este tipo de ceremonias, ya que con él jura acatar y defender los derechos y privilegios de la ciudad", ${ }^{90}$ recebendo as chaves da cidade e, embaixo do pálio, ${ }^{91}$ percorrerá as ruas principais sob aclamação em direção a catedral ou igreja principal. ${ }^{92} \mathrm{~A}$ influência das concepções religiosas levava os reis "a la iglesia principal, para escuchar los oficios y dar gracias al Señor, del mismo modo que Jesucristo acabó su entrada llegando al templo", 93 onde o monarca era recebido pelas autoridades religiosas para prestar "un nuevo juramento, esta vez de los privilegios e derechos eclesiásticos". ${ }^{94}$ No Período Moderno, graças ao Renascimento, as entradas régias resgataram as tradições das entradas romanas, mas também das medievais, originando um modelo de entrada triunfal que tinha "el esquema medieval de recibimiento extramuros, desfile triunfal y culminación en el templo principal", 95 mas recuperava o mundo antigo clássico, "tanto en tipologías - arcos efímeros, retratos o esculturas - como en iconografía grecorromana, ahora al servicio de los gobernantes modernos: mitología, retratos de emperadores y héroes o alegorías". ${ }^{96}$ Nesse conjunto simbólico e político, destacou-se o arco triunfal que, se por um lado, recuperou a porta da muralha medieval e o simbolismo de ultrapassar uma porta "estuvo siempre presente en las diferentes culturas europeas, signo de paso a otro mundo, de purificación, repleto de

87 CHIVA BELTRÁN, Juan. El Triunfo del virrey. Glorias novohispanas: origen, apogeo y ocaso de la entrada virreinal. Castelló de la Plana: Publicacions de la Universita Jaume I, 2012. p. 28.

88 Era preciso uma grande vitória militar, com pelo menos 5 mil baixas feitas ao inimigo, imposta por comandantes oriundos do estrato social mais elevado que "cumpliesen la doble cualidad de ser comandantes en jefe y magistrados de primer grado". A autorização do Senado e o financiamento público do evento configurava o cerimonial no seu nível mais elevado, o triumphus. A alternativa, quando não era autorizado o gasto público, era uma cerimônia semelhante, mas inferior e sem a mesma distinção, 0 ovatio (Juan Chiva Beltrán. El Triunfo del virrey..., p. 27-33).

89 CHIVA BELTRÁN, Juan. El Triunfo del virrey..., p. 29.

90 Id. , ibid., p. 40.

$91 \mathrm{Em}$ primeiro lugar, andar debaixo do pálio era uma distinção atribuída a poucos no Antigo Regime. Era o pálio um ornamento de tecido "prezo no alto de huas varas, debayxo do qual [...] em certas occasioens se vão receber Principes Ecclesiasticos, ou seculares [...]" (BLUTEAU, D. Raphael. Vocabulario Portuguez..., v. VI, p. 553). Covarrubias ressalta que "También usan dél los reyes en las primeras entradas en las ciudades" (Sebastián de Covarrubias. Tesoro de la Lengua Castellana o española..., p. 846).

920 séquito que acompanhava os monarcas nas entradas medievais estava organizado segundo uma hierarquização social clara.

93 CHIVA BELTRÁN, Juan. Op. cit., p. 39.

94 Id., ibid., p. 42.

95 Id., ibid., p. 44.

96 Id. , ibid., p. 44. 
honores", 97 na Época Moderna, por outro, tornou-se um arco efêmero, temporário, erguido para a entrada de governantes: "normalmente será de tipología clásica, con una inscripción conmemorativa y con al menos una imagen de la persona a la que se homenajea, y se llena además de escudos heráldicos, emblemas, divisas o alegorías". 98

Esses elementos rituais, cerimoniais e simbólicos, com marcado conteúdo político, estão presentes, com maior ou menor ostentação e pompa, nas entradas e tomadas de posse dos governantes enviados para as conquistas ultramarinas europeias da América, mantidas, em linhas gerais, as etapas básicas: recepção extramuros, entrada triunfal acompanhada de autoridades, com término na igreja principal. A disseminação desse cerimonial de entrada e posse, resultado da associação da experiência das entradas romanas, medievais e renascentistas ou modernas, esteve presente, nas diferentes colonizações da América, respeitadas as particularidades de cada um dos países europeus, autores dessas ações colonizadoras.

Na América colonial britânica, a "província real tornou-se o tipo normal de colônia e um sistema constitucional uniforme prevaleceu na maior parte" ${ }^{\prime 99}$ dessa região da América do Norte, e, apesar dessas conquistas inglesas resultarem da ação de empresas de acionistas, de concessões régias de donatarias ou de iniciativas individuais e coletivas não autorizadas, gradualmente, "a propriedade privada deu lugar a um controlo real; as donatarias foram objecto de renúncia ou anuladas e os assentamentos não autorizados, foram absorvidos por seus vizinhos devidamente constituídos". ${ }^{100}$ John Elliott ressalta que a natureza dos governos das colônias britânicas da América permitiu mais possibilidades para o exercício independente de um poder político eficaz, pois era uma sociedade que "funcionaba dentro de una cultura política con mayores fundamentos en conceptos de representación". ${ }^{101}$ Por isso, na América britânica colonial, conforme analisa Jack P. Greene, houve a "reprodução de variantes das culturas baseadas na lei comum", ${ }^{102}$ culturas essas que, mesmo diferindo de um espaço político territorial para outro, ${ }^{103}$ "de acordo com o costume local, permitiam-lhes adaptar com enorme flexibilidade a lei as condições locais, ainda que thes imprimissem um carácter resolutamente, senão militantemente, inglês". ${ }^{104}$ Mesmo sem ter a pompa e a ostentação dos vice-reis espanhóis, alguns dos governadores providos para a América britânica levavam um grande séquito de criados. Na sua chegada, o novo governador era recebido por "una salva de

\footnotetext{
97 CHIVA BELTRÁN, Juan. El Triunfo del virrey..., p. 47.

98 Id. , ibid., p. 47.

99 LABAREE, Leonard W. Royal government in America. New York/USA: Frederick Ungar Publishing Co., 1964. p. IX, (tradução do autor).

100 Id. , ibid., p. IX (tradução do autor).

101 ELLIOT, John H. Imperios del Mundo Atlántico..., p. 211.

102 GREENE, Jack P. Reformulando a identidade inglesa na América britânica colonial: adaptação cultural e experiência provincial na construção de identidades corporativas. Almanack Braziliense, n. 4, nov. 2006 , p. 10.

103 Segundo Jack P. Greene, foram as unidades provinciais - as colônias britânicas - o principal local da ação política e, por isso mesmo, "os principais locais de negociação da distribuição de autoridade" (Jack P. Greene. Reformulando a identidade inglesa na América britânica colonial..., p. 21).

104 GREENE, Jack P. Op. cit., p. 10.
} 
diecisiete disparos de los cañones del puerto y una recepción en el muelle". ${ }^{105} \mathrm{Na}$ saída da doca, passava por fileiras formadas pela milícia local, seguia em direção ao State House (edifício onde se reunia a Assembleia Colonial), onde "se leía su nombramiento y él juraba su cargo". ${ }^{106}$ A posse, caracterizada por uma relativa informalidade, comparada aos seus equivalentes na América Espanhola e no Estado do Brasil, terminava, diferentemente da lusoespanhola, com um jantar na taberna local.

A entrada e a posse dos governadores-gerais do Estado do Brasil aconteciam em cerimônia pública e, a orientação seguia uma fórmula definida nos regimentos que indicavam que ela deveria acontecer logo após o desembarque em Salvador, na presença dos que estivessem exercendo a governação, autoridades, representantes da população e das elites locais, ${ }^{107}$ com a cerimônia de posse acontecendo na Igreja da Sé. ${ }^{108}$ Essas entradas e cerimônias de posse eram marcadas pela pompa e pela solenidade, como podemos depreender de Frei Vicente Salvador, sobre a chegada de Diogo Luís de Oliveira a Pernambuco, quando por lá passou, antes de se dirigir à Bahia, em novembro de $1625 .{ }^{109}$ Por quatro dias ele ficou em Recife, antes de se dirigir a Olinda. Na entrada da cidade, "na porta da alfândega estava um arco triunfal de muito boa arquitetura, ornado de bons versos, emblemas e epigramas em seu louvor", 110 em seguida, soldados arcabuzeiros se estenderam "ao longo das paredes até a Misericórdia, onde estava outro arco não com menos perfeição lavrado e ornado". Ouviu as palavras do vereador mais velho da vila e "o levaram debaixo do pálio até a igreja matriz", seguido de algumas autoridades "e o povo todo de Olinda com muito aplauso"; depois, "feita oração e as cerimônias costumadas [apresentação de credenciais e tomada de posse do governo], levaram à casa do seu antecessor, que já lha tinha pera isso desocupada". A maior parte dos governadores-gerais e vice-reis realizaram sua entrada e posse na Bahia, e a Câmara de Salvador preparava a recepção dos governadores, como podemos concluir de

105 ELLIOT, John H. Op. cit., p. 215-216.

106 ELLIOT, John H. Op. cit., p. 216.

107 No regimento de Francisco Giraldes (1588), deveriam se reunir os que compunham o governo interino: "o Bispo [...] o Provedor [...] e o Ouvidor Geral, aos quais ou aos que forem presentes sendo também chamados os Juízes Vereadores da dita Cidade" (MENDONÇA, Marcos Carneiro de. Raízes da Formação Administrativa do Brasil. Rio de Janeiro: IHGB/Conselho Federal de Cultura, 1972. p. 259-260). No de Gaspar de Sousa (1612), deveriam se reunir "os Juizes, vereadores, Procurador e Oficiais que servirem à Câmara da mesma Cidade, e o Ouvidor-Geral e mais Desembargadores da dita Relação"(MENDONÇA, Marcos Carneiro de. Op. cit., p. 433). No de Diogo de Mendonça Furtado (1621), a orientação era juntar "as pessoas que nestes actos se achão ordinariamente" (Arquivo Publico do Estado da Bahia - S. C., estante 1, caixa 146, livro 264). Assim, uma vez reunidos os indicados na instrução régia, conforme o regimento de 1588, deveria ser mostrada a patente "para, desde aquela hora em diante ficardes em posse dele, e vos haverem por entregue a dita governança, de que não usarão mais em cousa alguma [...]" (Marcos Carneiro de Mendonça. Raízes da Formação Administrativa do Brasil...., p. 259). O regimento de 1677 repetiu essa fórmula.

108 SALVADOR, Frei Vicente. História do Brasil. São Paulo: Edições Melhoramentos, 1975, p. 354.

109 Recife foi, por algum tempo, residência dos governadores-gerais do Estado do Brasil de 1602 a 1621 (de Diogo Botelho até D. Luiz de Sousa).

110 SALVADOR, Frei Vicente. Op. cit., p. 420. As citações seguintes desse parágrafo têm a mesma referência. 
algumas referências empíricas encontradas em assentos da Câmara da cidade ${ }^{111}$ e da carta para o Conselho Ultramarino enviada por D. Pedro António de Noronha Albuquerque e Sousa, marquês de Angeja. ${ }^{112}$

$\mathrm{Na}$ carta enviada pelo marquês de Angeja, em 18 de julho de 1714, a Diogo de Mendonça Corte Real, secretário de Estado de D. João V, relatando sua chegada, entrada e posse no governo, podemos conhecer mais detalhadamente como se desenvolvia essa prática cotidiana do cerimonial de poder do governo-geral/vice-reinado do Estado do Brasil. D. Pedro António de Noronha Albuquerque e Sousa, que foi vice-rei da Índia, narra como se desenvolveu a cerimônia e, com muito estranhamento, descreve a informalidade com que foi organizado todo o cerimonial. ${ }^{113}$

Na descrição de Angeja, ia "o governador [em exercício] buscar o seu sucessor a bordo e leva-lo para o Colégio dos Padres da Companhia; donde passados os dias que sempre são três ou quatro"114 se realizava "a entrada e [a] entrega [do poder] e a Cerimonia é vir o Senado da Câmara e todos os Cidadãos com varas vermelhas a busca-lo ao Colégio". ${ }^{115} \mathrm{O}$ governador e o seu antecessor iam "debaixo de Palio cujas varas levam os Vereadores e Cidadãos"116 em direção a Igreja da Sé "aonde esta o Arcebispo só com a sua murça117 e rochete $^{118}$ e o cabildo". ${ }^{119} \mathrm{O}$ arcebispo "deita água benta ao novo Governador, lhe da a Cruz a beijar". ${ }^{120} \mathrm{O}$ arcebispo e os dois governadores, o que está assumindo o governo e o que está saindo, vão "conversando até a Capela do sacramento, aonde fazem oração e dai passão a Capela mor, o novo Governador a mão esquerda do que acaba [e] se sentam em setial ${ }^{121}$ não

\footnotetext{
111 Documentos Históricos do Arquivo Municipal. Atas da Câmara, 1625-1641, 1. v. Bahia: Prefeitura do Município do Salvador, 1949, p. 442; e Documentos Históricos do Arquivo Municipal. Atas da Câmara, 1641-1649, 2. v. Bahia: Prefeitura do Município do Salvador, 1949, p. 118.

112 Avulsos da Bahia - Arquivo Histórico Ultramarino. ACL - CU - 005, cx. 9, doc. 745, fol. 1. Esse é um dos poucos relatos conhecido sobre a entrada e posse de governadores no Estado do Brasil, por isso a importância desse documento. Ele também está relatado em RUY, Afonso. História política e administrativa da cidade de Salvador. Bahia: Tipografia Beneditina, 1949, p. 177, entretanto sem a menção de que a carta faz parte do acervo do AHU.

113 Chama a atenção o conhecimento que o marquês de Angeja tem das entradas de governantes em outras monarquias, por isso sua censura a irregularidade e informalidade como a cerimônia desenvolveuse na Bahia. Segundo ele: "A forma em que se faz a entrega deste governo e são recebidos os governadores, e o fui eu ainda que vice-rei, é a mais incurial e pouco formal a que eu experimentei na India, e tenho lido dos Reinos e Estados aonde costuma haver Vice-Reis" (Avulsos da Bahia - Arquivo Histórico Ultramarino. ACL - CU - 005, cx. 9, doc. 745, fol. 1).

${ }_{114}$ Avulsos da Bahia - Arquivo Histórico Ultramarino. ACL - CU - 005, cx. 9, doc. 745, fol. 1.

115 Avulsos da Bahia - Arquivo Histórico Ultramarino. ACL - CU - 005, cx. 9, doc. 745, fol. 1.

${ }_{116}$ Avulsos da Bahia - Arquivo Histórico Ultramarino. ACL - CU - 005, cx. 9, doc. 745, fol. 1.

117 Murça, segundo Bluteau, é "Vestidura curta \& sem mangas, com seu capelinho atraz, abotoada por diante; dela usão Conegos, Bispos, \& outros Ecclesiasticos, sobre a sobrepeliz ou sobre o Rochete" (BLUTEAU, D. Raphael. Vocabulario Portuguez e Latino..., v. V, p. 643).

118 "Rochete ou Roxete ou Roquete. Vestimenta Episcopal. He hua espécie de sobrepeliz de Cambray ou linho muyto fino, com as mangas justas ate o cotovelo com sua renda por bayxo, cortada pela medida do Bispo de corte que não chegue ao joelho \& que pondo-se de joelhos não toque a renda o Chão" (BLUTEAU, D. Raphael. Op. cit., v. VII, p. 352).

${ }_{119}$ Avulsos da Bahia - Arquivo Histórico Ultramarino. ACL - CU - 005, cx. 9, doc. 745, fol. 1.

120 Avulsos da Bahia - Arquivo Histórico Ultramarino. ACL - CU - 005, cx. 9, doc. 745, fol. 1.

121 O setial não de cortina, mas, de espaldar é um símbolo de distinção que constata a qualificação de representação da pessoa real que tinham os governadores-gerais e vice-reis, pois, esse "Banco, ou genuflexório" era usado "para pessoas Reaes se encostarem, \& se porem de joelhos" (BLUTEAU, D. Raphael. Op. cit., v. VII, 665).
} 
de cortina, mas, só de espaldar". ${ }^{122}$ Continua o marquês de Angeja a sua carta descrevendo a entrada dos "Vereadores, Ministros e toda a mais gente que ai se acha na Capela mor, lê o Secretario do Estado a Patente e acabada de ler entrega o Governador o bastão ${ }^{123}$ ao sucessor e mudam de Cadeiras, passando para a mão direita ${ }^{124}$ o novo Governador". ${ }^{125}$ Empossado o novo governo, "se levantam e, o Arcebispo com o Cabildo, os torna a vir acompanhar e, no meio da Igreja, [se] viram os Govenadores um para o outro, e, se despedem: o que acaba toma a porta travessa e o outro vai para a principal até onde o acompanha o Arcebispo". ${ }^{126} \mathrm{O}$ governador recém-empossado vai para a porta principal da Sé "onde o acompanha o Arcebispo e tornando a meter-se debaixo do Palio é trazido pelo mesmo Senado e mais acompanhamento de gentes até a porta de palácio e [onde] pegam nas armas as Milícias e os Terços pagos". ${ }^{127}$

Mais complexas e longas eram as entradas e as posses dos vice-reis da América Espanhola. Na verdade, o processo começava bem antes que eles chegassem à América. No caso dos vice-reis espanhóis, o ritual tinha início após a nomeação e incluía a viagem do vicerei nomeado, sua família e seus serviçais até Sevilha, onde acontecia seu embarque para a América.

É importante entender que os vice-reis, ao incorporarem ao "su cargo el nivel superior de todas las funciones del soberano en el territorio que se les encomendaba gobernar en su nombre"128 e, em razão da sua condição de "viva imagen del rey lo constituía en el centro manifiesto del poder $[. .$.$] y, como tal, los rituales políticos [...] siempre giraban alrededor de$ su figura". ${ }^{129}$ Por isso, disfrutaram, por conta do seu cargo e da dignidade que isso lhes dava, "el uso y observancia de las mismas ceremonias que se hacen a nuestra Real persona dentro y fuera de nuestra Capilla". ${ }^{130}$ Assim, como representação do rei, usufruem das dignidades próprias da pessoa real e, em razão disso, a Recopilacion de Leyes de los Reynos de las Índias autoriza que "los Vireyes usen de sitial en las Iglesas y lugares en que concurrieren y asistiren, como siempre lo han usado". ${ }^{131}$

\footnotetext{
122 Avulsos da Bahia - Arquivo Histórico Ultramarino. ACL - CU - 005, cx. 9, doc. 745, fol. 1.

123 Entre os portugueses, o bastão "he quase sempre insígnia de mando, particularmente na guerra" (BLUTEAU, D. Raphael. Op. cit., v. II, p. 62).

${ }^{124} \mathrm{~A}$ troca de lugar e sentar-se à direita tem relação com a importância atribuída a esse lugar na cultura católica onde "Christo Senhor Nosso esta sentado a mão direita de deos Padre, quer dizer, que em quanto Deos, tem igual glória com o pay, \& em quanto homem, mais que todas as criaturas" (BLUTEAU, D. Raphael. Op. cit., v. III, p. 236).

${ }^{125}$ Avulsos da Bahia - Arquivo Histórico Ultramarino. ACL - CU - 005, cx. 9, doc. 745, fol. 1.

${ }^{126}$ Avulsos da Bahia - Arquivo Histórico Ultramarino. ACL - CU - 005, cx. 9, doc. 745, fol. 1- 1v.

127 Avulsos da Bahia - Arquivo Histórico Ultramarino. ACL - CU - 005, cx. 9, doc. 745, fol. 1v.

128 RIVERO RODRÍGUEZ, Manuel. Una monarquía de casas reales y cortes virreinales..., p. 47.

129 CAÑNEUE, Alejandro. De sillas y almohadones o de la naturaleza ritual del poder en la Nueva España..., p. 616.

${ }_{130}$ RLRI, Tomo I, Libro III, Tít. XV, p. 632.

131 RLRI, Tomo I, Libro III, Tít. XIIII, p. 630. O uso do sitial constata a qualificação de representação da pessoa real dos vice-reis, pois, segundo Bluteau, apenas as pessoas reais o utilizavam. Segundo ele, sitial é o "Banco, ou genuflexorio, cuberto de hum pano de damasco, ou veludo com hua almofada em cima, \& e outra em bayxo, ou mais almofadas, para as pessoas Reaes se encostarem, \& se porem de joelhos" (BLUTEAU, D. Raphael. Vocabulario Portuguez e Latino..., v. VII, p. 665).
} 
Luis González Obregón ${ }^{132}$ descreve a viagem de Diego López Pacheco y Portugal, duque de Escalona, Grande de Espanha, nomeado por Felipe IV em 1640. ${ }^{133}$ Depois de fazer seu testamento, o duque partiu de Escalona em 10 de março e com sua comitiva passou por Toledo, Moro, Consuegra, Membrilla, Villaharta, Andújar, Córdoba, Ecija, Fuentes, Carmona, Utreta, Lebrija, "y desde Lebrija al puerto en que habla de embarcarse; y en todas partes por donde atravesó encontró particular amor, agasajos, reconocimientos y veneraciones, quedando todos favorecidos con su presencia, socorridos con sus limosnas y pagados con su agrado". ${ }^{134}$ A partida aconteceu em 20 de abril, em uma travessia que durou cerca de dois meses e meio levando o duque e sua comitiva,

[...] dos mil gallinas, doce terneras y doscientos carneros en la nao Capitana, sin lo que traía la familia del Virrey: además, seis baúles de vara y media, conteniendo dulces, aparte un gran número de cajas, pipotes, yorzas de almíbares y muchas cajas de bizcochos, cubiertos y tostados, "siendo verdad que de lo demás de bizcochos, jamones, arroz, fideos, lentejas, castañas, garbanzos, vino y pastas y otras cosas quedó sobrado para otro viaje". ${ }^{135}$ (Grifo nosso)

Chegando ao México, o novo vice-rei foi recebido por uma salva de tiros e pelas "autoridades y lo principal del vecindario, con mucho lujo en sus trajes para hacer los debidos acatos a su nuevo virrey". ${ }^{136} \mathrm{O}$ duque de Escalona vestia "un traje corinto, bordado de plata, con cabos blancos, gregüescos acerados, calzas de punto, botas de valdés, ancha gorguera, sombrero con plumas y con joyel de perlas y banda roja cruzada por el pecho". ${ }^{137}$ Depois da recepção e da missa, era costume os vice-reis ficarem alguns dias na cidade para o

132 Vamos utilizar como apoio, além de outros trabalhos e fontes, dois historiadores mexicanos do início do século XX, Luis González Obregón e Artemio Valle-Arizpe. Membros de uma geração numerosa, são assim analisados pela historiografia contemporânea mexicana: "la vasta obra de investigación y creación de los humanistas, políticos e historiadores mexicanos de 1900-1940, quienes ponen en juego uno de los procesos substanciales del conocimiento en México: una historia de su cultura, que es al mismo tempo historia de las prácticas sociales, de la escritura, de la fundación de un proyecto nacional estatal, de la función misma del autor en los órdenes de la clasificación, asignación y distribución de los textos; es decir, de las representaciones vivas y fundamentales del pasado que hasta hoy se proyectan sobre nuestro futuro" (BERENZON GORN, Boris. La construcción del discurso historiográfico "mexicano" (19001940). In: Historiografía, herencias y nuevas aportaciones. México: La Vasija A. C. Editores, 2003. p. 8788). Obregón trabalhou no Museu Nacional de Antropologia e História, foi responsável pelas publicações da Biblioteca Nacional do México e membro da Academia Mexicana de Língua e História. Fundou e presidiu o Arquivo Geral da Nação. Valle-Arizpe foi, a partir de 1919, embaixador na Espanha, Bélgica e Holanda. Durante sua estada na Espanha teve contato com o Archivo de Indias interessando-se pela História colonial mexicana.

133 Diego López Pacheco y Portugal era duque de Escalona; marquês de Villena y de Mora, conde de Xiquena e de San Esteban de Gormaz, Grande de Espanha. Foi coronel de infantaria e, depois da Nova Espanha foi nomeado em 1649, vice-rei de Navarra. Filho de Dona Serafina de Bragança, filha segunda do D. João VI, duque de Bragança e de Dona Catarina de Bragança (pretendente ao trono em 1580), teve problemas quando da Restauração portuguesa, foi destituído e, ao chegar à Espanha, "logro hacer patente su lealtad ante Felipe IV" e, por "Cedula Real librada en Madrid em 28 de enero de 1647, se mandó reponerle en el mando" (RUBIO MANÉ, José Ignacio. El Virreinato, I. Orígenes y jurisdicciones...., p. 148). Preferiu o governo de Navarra. Ver: MONTORO, José. Virreyes Espanõles em America. Barcelona: Editorial Mitre, s/d.

134 GONZÁLEZ OBREGÓN, Luis. Croniquillas de la Nueva España. México: Ediciones Botas, 1957. p. 52.

135 Id., ibid., p. 52.

136 VALLE-ARIZPE, Artemio de. Virreyes y virreinas de la Nueva España. México: Aguilar Editores, 1976. p. 83

137 Id., ibid., p. 83 
cumprimento de obrigações formais, como por exemplo, a inspeção das fortalezas da região, e não foi diferente com o duque de Escalona.

O caminho em direção à Cidade do México era marcado de um forte conteúdo simbólico e político, pois seguia "la ruta a la capital recorrida por Hernán Cortés"138 ou quase isso ${ }^{139}$, recriando a conquista espanhola da Nova Espanha. Começava o trajeto do vice-rei em direção à capital, pela cidade de Tlaxcala - "la ciudad india [...] que había apoyado lealmente a Cortés durante la conquista de México"140 - onde, para os vice-reis que chegavam, inclusive o duque de Escalona, "se representaron comedias y se entregaron [...], en una suntuosa ceremonia, las llaves de la ciudad hechas de oro y hierro, símbolo ese damasquinado del carácter de Su Excelencia: la dulzura maleable del oro dentro de la fuerza del hierro". ${ }^{141}$ O passo seguinte era a entrada na cidade de Puebla - "ciudad criolla [...] para rendir análogo homenaje a los conquistadores españoles"142 - onde permanecia por alguns dias antes de seguir viagem em direção à Cidade do México. A viagem prosseguia passando por Cholula onde os "representaron los frailes de San Francisco comedias religiosas; en Huexotcingo le salieron a recibir los cuatro gobernadores de indios, vestidos como los antiguos señores"143 e chegava a Otumba, "escenario de la primera victoria de Cortés tras la retirada de Tenochtitlán". ${ }^{144}$ Era nessa cidade que os vice-reis da Nova Espanha recebiam o governo e tomavam posse dele, entrando o vice-rei "en pleno ejercicio de la autoridad desde que [o virrey que estaba de salida] le entrego el bastón de mando". ${ }^{145}$ Segundo a descrição de Valle-Arizpe, "La entrega fue solemne, llena de reverencias y de palabras afectuosas entre una gran pompa y esplendor magnífico. Delegados de la Audiencia, [...] de los tribunales, fueron rendir pleito homenaje al nuevo Virrey". ${ }^{146}$ Transferido o poder, o vice-rei que estava de saída, entregava o governo ao que chegava e, na grande maioria dos casos, seguia seu caminho de volta para a Espanha, ${ }^{147}$

138 ELLIOT, John H. Imperios del Mundo Atlántico..., p. 200.

139 Segundo León Mariscal, tirando como modelo a chegada e o trajeto do marquês de las Amarillas (1755-1760), "Pese a que el trayecto no seguía estrictamente la ruta de Hernán Cortés hacia la cabeza del imperio mexica, al partir de la primera población fundada por el conquistador y al recorrer lugares que gozaban del privilegio de entrada a caballo, se traían a la memoria hechos transcendentales de la conquista de México así como la grandeza material y espiritual del virreinato. En consecuencia, el camino de un virrey a México adquirió un significado histórico y triunfal propio, en el que se evocaba el origen heroico y pactista del reino, se exaltaba la excelencia del mismo, y se manifestaba la voluntad divina en hechos legendarios o sobrenaturales" (LEÓN MARISCAL, Beatriz Berndt. Discursos de poder en un nuevo dominio: el trayecto del virrey marqués de las Amarillas de Veracuz a Puebla, las fiestas de entrada y el ceremonial político. In: Relaciones, n. 101, v. XXVI. México, 2005. p. 254).

140 ELLIOT, John H. Op. cit., p. 201.

141 VALLE-ARIZPE, Artemio de. Op. cit., p. 85.

142 ELLIOT, John H. Imperios del Mundo Atlántico..., p. 201.

143 GONZÁLEZ OBREGÓN, Luis. Croniquillas de la Nueva España..., p. 60.

144 ELLIOT, John H. Op. cit., p. 200.

145 VALLE-ARIZPE, Artemio de. Op. cit., p. 228. Passamos agora a mesclar descrições do duque de Escalona com o relato da entrada do marquês de las Amarillas, Don Agustin de Ahumada y Villalón, comendador da rainha da Ordem de Santiago, tenente-coronel do Exército Real e da Guarda Real, governador de Barcelona, gentil-homem da Câmara do rei.

146 VALLE-ARIZPE, Artemio de. Op. cit., p. 237.

147 De 42 vice-reis efetivos, excluílos os interinos, normalmente o arcebispo do México, durante os séculos XVI, XVII e XVIII, apenas 8 saíram da Nova Espanha e assumiram o vice-reinado do Peru. Foram eles: Antonio de Mendonza, Luis de Velasco, o conde de Monterrey, o marquês de Montesclaros, 0 
enquanto o novo governante, que ia assumir o governo, dirigia-se a Chapultepec, onde acontecia, efetivamente, a entrada e posse do vice-rei no governo da Nova Espanha.

Era em Chapultepec, "residencia o palacio de recreo de los virreyes cercano a México", ${ }^{148}$ que a transferência completa do poder acontecia. O novo vice-rei saía do Palácio de Chapultepec em carruagem ricamente adornada - a do duque de Escalona era "una carroza vestida de damasco maravillosamente bordado y con guarniciones de oro y coral"149 -, acompanhado pela população. Por todo o trajeto atravessava arcos adornados com diversos materiais e escritos alusivos ao acontecimento, realizando a "marcha virreinal, triunfo romano y entrada renacentista a partes iguales". ${ }^{150} \mathrm{Na}$ entrada da cidade, o vice-rei montava num "bayo rodado, con silla de ámbar, adornada con bordaduras, bellotas de oro y altos entorchados, cubierta con telliza de tela de Milán", ${ }^{151}$ oferecido pelo Cabildo da cidade, sendo o cortejo acompanhado por funcionários régios, religiosos, o poder local e a nobreza da terra. A posse acontecia na entrada da Cidade do México, à vista de todos, quando o "Virrey llegó al primer arco [...] y bajo de él le recibieron el corregidor y la Nobilísima el juramento de fidelidad y el de guardar los fueros de la Ciudad", ${ }^{152}$ compromisso registrado pelo escrivão do Cabildo. Eram entregues ao vice-rei, numa "bandeja de plata repujada, las llaves, que eran de oro $[. .$.$] ", e seguia este para a catedral, acompanhado por autoridades civis e religiosas, "bajo$ el palio [...] [con] sus varas de plata maciza, las tomaron los regidores más antiguos", 153 apesar da sua proibição decretada por Felipe II em $1573^{154}$ e sancionada por todos os seus sucessores. ${ }^{155}$ A posse formal, cerimônia revestida de símbolos de poder renovadores da autoridade régia, ocorria no palácio vice-reinal, diante da Audiência do México. Sentava-se o vice-rei em um "sillón de alto y tallado respaldo con forro de damasco y franjas de oro y a sus pies un ancho cojín, también rojo y con galones y borlas"156 e, em cada lado de seu trono, havia seis assentos para os ouvidores. A cerimônia tinha início sob o comando do vice-rei que ordenava a entrada do selo real trazido pelo chanceler que "iba cubierto y armado de todas sus armas; lo acompañaban doce ministros de la Audiencia con gruesas hachas de cera de las

marquês de Guadalcázar, o conde de Salvatierra, o conde de Alba de Aliste e o conde de Monclova, alcançando menos de $20 \%$ do total, situação que, é bom que se diga, ocorreu apenas durante os séculos XVI e XVII.

148 RIVERO RODRÍGUEZ, Manuel. Op. cit., p. 184.

149 VALLE-ARIZPE, Artemio de. Op. cit., p. 90-91.

150 ELLIOT, John H. Op. cit., p. 201.

151 VALLE-ARIZPE, Artemio de. Op. cit., p. 91.

152 Id., ibid., p. 231.

153 Id., ibid., p. 231.

154 "Que los Virreyes no usen de la ceremonia del palio en sus recibimientos: y en el del Perú se pueden gastar hasta doce mil pesos: y en el de Nueva España hasta ocho mil" (RLRI, Libro III, Tít. III, Ley XIX).

155 León Mariscal, em seu estudo sobre a entrada do marquês de las Amarillas, afirma que ele "se negó a aceptar dicha ceremonia conforme lo hizo con anterioridad en Veracruz, Tlaxcala y el convento de San Francisco pues estaba reservado al Santísimo Sacramento, al rey y al papa, además de que por ley estaba estipulado "[...] que los virreyes del Perú, y Nueva España, cuando pasasen, y llegaren a sus virreinatos, no usen de la ceremonia de ser recibidos con palios, y guiones, con sus armas en las Ciudades de Lima y México, ni en otras cualesquier Villas y Lugares, porque esto sólo pertenece a nuestra Real persona" (LEÓN MARISCAL, Beatriz Berndt. Discursos de poder en un nuevo dominio: el trayecto del virrey marqués de las Amarillas..., p. 251).

156 VALLE-ARIZPE, Artemio de. Op. cit., p. 238. 
de cuatro mechas"157 e o colocava ao lado do vice-rei que "lo tomó en señal de posesión y en seguida exhibió las tres cédulas del rey [...] que leyeron los dos secretarios de cámara y de gobierno"158 onde estava a nomeação como capitão- geral, vice-rei e presidente da Audiência do México. Em seguida, os ouvidores "fueron poniendo sobre la cabeza, en señal de acato, de sumisión y de obediencia, El Virrey hizo el solemne juramento sobre los santos Evangelios y entregó al canciller el sello real, quien se lo llevó". ${ }^{159}$ Depois disso, o vice-rei retornava à catedral e, mais tarde, iam ao palácio vice-reinal, "lo más distinguido y encumbrado de la sociedad mexicana para presentar sus respetos a los virreyes, lo cual dio ocasión a un festejo que hicieron los más diestros músicos de la ciudad". ${ }^{160}$

\section{Poderes e entradas de governadores e vice-reis do Estado do Brasil e do Reino da Nova Espanha: algumas conclusões}

Percebemos que na entrada dos governadores-gerais e vice-reis existiam ações, ritos e cerimônias que eram comuns, próprios da representação do poder régio, simbolizada, em maior ou menor escala, por esses governantes, inclusive, apesar da breve apresentação, os governadores da América colonial inglesa. A tradição romana, medieval e renascentista, reinterpretada e amalgamada aos costumes de cada monarquia, explica, em parte, essa similitude, associada à necessidade de fazer presentes e visíveis elementos simbólicos representativos do poder régio, em regiões tão distantes da sede do governo e de um monarca, cotidianamente ausente.

Por outro lado, tratando especificamente do Estado do Brasil e da América Espanhola, destacadamente do Reino da Nova Espanha, chama atenção, além das semelhanças refinadas em suas influências quando da união das monarquias entre 1580 e 1640, as diferenças não apenas dos poderes dos governos ultramarinos de cada uma das monarquias, mas das relações políticas, institucionais e rituais com as instituições presentes em terras americanas. Assim, chama atenção o fato de que a apresentação das credenciais e as cerimônias que aconteciam no Estado do Brasil tinham, na Câmara Municipal da Bahia, um personagem relevante. Ao passo que, se o Cabildo do México está presente na entrada e posse dos vicereis, os personagens centrais são os membros da Audiência, conforme os relatos e registros apresentados. Isso se deve, no nosso entendimento, aos poderes e às funções desempenhadas pelas Audiências hispano-americanas, ao poder mais alargado do vice-rei da Nova Espanha em relação ao governador-geral do Estado do Brasil e também ao maior protagonismo de que dispunham as Câmaras Municipais nas conquistas portuguesas em relação aos Cabildos hispano-americanos. ${ }^{161}$ Queremos aqui destacar dois aspectos sobre essa diferença. O primeiro

157 Id., ibid., p. 238.

158 Id., ibid., p. 238.

159 Id., ibid., p. 238.

160 Id. , ibid., p. 238-239.

161 Queremos deixar claro, para evitar interpretações equivocadas, que não estamos aqui entrando no debate a respeito do poder local nas partes americanas das monarquias ibéricas, mas apenas pontuando a respeito do papel que a Câmara da Bahia e o Cabildo do México desempenhavam, ou não, na recepção 
aspecto diz respeito às Audiências. Organizadas desde 1511, com a da Nova Espanha formada em 1530, elas significaram, conforme apresenta a historiografia, ${ }^{162}$ o começo da presença cotidiana do poder da monarquia castelhana no Novo Mundo, cinco anos antes do envio do primeiro vice-rei. Era por esses tribunais que passava todo o funcionamento dos mais diversos cabildos hispano-americanos, inclusive seus contatos com o monarca, fazendo com que as Audiências, na prática, filtrassem, controlassem e limitassem os órgãos locais de poder. ${ }^{163} \mathrm{O}$ segundo, não trata da ausência no Estado do Brasil e na sua sede, Salvador, de um tribunal superior, ele existia e era o Tribunal da Relação, presidido pelos governadores e criado à semelhança do que existia em Lima. ${ }^{164}$ Tal questão diz respeito aos diversos papéis políticos e administrativos $^{165}$ desempenhados pelas câmaras municipais na América lusa, ao contrário dos cabildos hispano-americanos, particularmente os que eram desempenhados pela Câmara da Bahia, localizada em Salvador, cabeça do Estado do Brasil ou, conforme Frei Vicente Salvador, o "coração no meio do corpo, donde todas se socorressem e fossem governadas"166. Assim sendo, as câmaras das conquistas portuguesas além de deterem o poder local e a gestão da república, conforme a percepção da cultura política dominante nesse momento e da historiografia, também as câmaras municipais, ao menos no Estado do Brasil e, em particular a Câmara de Salvador na Bahia, desempenharam o papel de representação política. Nessa parte distante do império ultramarino da monarquia pluricontinental portuguesa, o colegiado local representou a ideia de pacto e de mediação popular costumeira no pensamento político português desse momento. Segundo Xavier e Hespanha, citando um pensador português do século XVII, "conforme as regras do direito natural, e humano, ainda que os Reinos transferissem nos Reis todo o seo poder e império, para os governar, foi debaixo de uma tácita condição, de os regerem, e mandarem, com justiça e sem tyrania". ${ }^{167}$ As câmaras municipais

dos governantes maiores do Estado do Brasil e do Reino da Nova Espanha. Sobre o debate a respeito do poder local na América portuguesa e suas comparações com as partes espanholas, remeto a bibliografia disponível e conhecida.

162 ELLIOT, John H. Imperios del Mundo Atlántico..., p. 198.

163 CAÑO ORTIGOSA, José Luis. El Cabildo de Guanajuato y sus relaciones institucionales (1660-1800). Sevilla/España: Padilla Libros Editores \& Libreros, 2011. p. 15-22.

164 A criação e a instalação do Tribunal da Relação em 1609, sua dissolução em 1626 e a sua restauração em 1652, conforme o mesmo regimento inicial, originou, em terras brasileiras, um órgão judiciário superior que submeteu todo o encaminhamento das questões judiciárias, resguardando o direito de recurso, em alguns casos determinados, à casa de Suplicação em Portugal. Além disso, a Relação da Bahia funcionava como tribunal de recurso às decisões dos oficiais menores da justiça, tais como os ouvidores das capitanias e do ouvidor-geral e do provedor-mor dos defuntos. Atuavam os governadoresgerais como regedores, presidentes, da Relação. Conforme expõe Schwartz, diferente da Casa da Suplicação em Portugal, o Tribunal da Relação não tinha um regedor, mas quem desempenhava essa função era o governador. O autor destaca que esta "fórmula havia sido desenvolvida na Índia onde a função era desempenhada pelo vice-rei. A relação que o governador-geral do Brasil mantinha com a relação da Bahia, assemelhava-se àquela mantida pelo vice-rei do Peru com a Audiência de Lima" (SCHWARTZ, Stuart B. Burocracia e Sociedade no Brasil colonial. São Paulo: Editora Perspectiva, 1979. p. 51).

165 Os aspectos de história social envolvidos na Câmara Municipal não estão aqui sendo tratados. Isso exigiria um trabalho específico sobre câmaras. Estamos ressaltando o que, por sinal, os estudos de Câmara Municipal, não fazem: o papel político e administrativo desempenhado pela Câmara da Bahia no âmbito do Estado do Brasil, da monarquia e do Império português.

166 SALVADOR, Frei Vicente. História do Brasil..., p. 143.

167 XAVIER, Ângela Barreto e HESPANHA, António Manuel. A Representação da sociedade e do poder. In: História de Portugal. O Antigo Regime. 4. v., Lisboa: Editorial Estampa, 1998. p. 119. 
das partes do ultramar português eram a instituição que construíam a representação e a lembrança da monarquia portuguesa, por isso, seu papel de memória política e/ou de local no qual o maior representante do monarca nessa conquista, o governador-geral ou o vice-rei, apresentava suas credenciais e tomava posse formal do governo desse Estado. ${ }^{168}$

Por sua vez, demonstrando uma sofisticação e um refinamento na gestão do poder e da administração de suas conquistas ultramarinas oriundas de uma monarquia compósita acostumada a transferir para vice-reis poderes régios, os governantes da América espanhola, destacadamente do Reino da Nova Espanha, dispunham de mais poderes e qualificação social do que os governadores-gerais e vice-reis do Estado do Brasil, mesmo quando, no século XVIII, foram enviados vice-reis para o Estado do Brasil, porém com os mesmos poderes dos governadores-gerais anteriores. Ao lado disso, era a Audiência, instituição de justiça presidida pelos vice-reis e constituída de funcionários nomeados pela monarquia e não os cabildos, uma instituição que tinha os seus cargos negociados, a instituição de referência na América espanhola. Não que os cabildos não desempenhassem, do ponto de vista político e administrativo, o papel de gestor da localidade, governo da república; desempenhavam, mas apenas isso.

Terminamos assim, este breve ensaio comparativo. A tentativa de comparar os governos e os poderes dos governantes das conquistas ultramarinas europeias é ainda um trabalho pouco explorado pela historiografia. Ela tem estado mais dedicada aos estudos específicos de certas experiências em termos de governos ultramarinos - Estado do Brasil, Reino de Nova Espanha, Nápoles, Navarra, Aragão Estado da Índia, etc. - mesmo quando reunidos numa mesma coletânea, ${ }^{169}$ ou tem realizado trabalhos mais focados em certos períodos ou espaços ultramarinos, particularmente na historiografia americana e europeia, sobretudo a espanhola, estudos por sinal bastante articulados e consistentes. ${ }^{170}$ No caso do ultramar português, ainda são poucos os estudos sobre o Estado da Índia, o Estado do Brasil e o Estado do Grão Para e Maranhão e as comparações que eventualmente são construídas se mostram ainda tímidas e limitadas. Para a Espanha e para a América espanhola, se a produção é bem expressiva, em parte, fruto de uma tradição de pesquisa latino-americana, norte-

168 É importante ressaltar que as Câmaras Municipais das conquistas ultramarinas portuguesas eram das instituições responsáveis pela guarda e registro dos diversos regimentos e leis emanadas do reino, funcionando como memória político-administrativa da monarquia nas suas conquistas. Nos regimentos de governo, em diferentes capítulos, estava indicado que o governador, ao chegar a seu destino, deveria apresentar-se à Câmara da localidade onde desembarcou e o seu regimento deveria ser registrado nos seus livros. Também seriam registradas pelas câmaras outras medidas emanadas do reino, como podemos ver no regimento do governador do Estado do Brasil que indicava que, além do registro nos livros da Câmara, da Secretaria e da Fazenda, deveria ocorrer a remessa dos "traslados com sua ordem aos Governadores, e Capitães-Mores de sua jurisdição, para que ordenem o mesmo, mandando-o registrar nos Livros de minha Fazenda, e Câmaras dos ditos Governos, e Capitanias" (Regimento de Roque da Costa Barreto. In: MENDONÇA, Marcos Carneiro de. Raízes da Formação Administrativa do Brasil..., p. 845-846).

169 Ver: CARDIM, Pedro, PALOS, Joan-Lluís. El mundo de los virreyes en las monarquías de España y Portugal. Madrid: Iberoamericana/Frankfurt: Vervuert, 2012.

170 Como o de Manuel Rivero Rodríguez, citado ao longo deste artigo. 
americana, europeia e espanhola, ${ }^{171}$ a comparação entre os espaços ultramarinos é também acanhada. Nesse sentido, este ensaio inicial mostra possibilidades de trabalho, sinalizando ausências e constatando necessidades.

Francisco Carlos Cardoso Cosentino: É professor associado da Universidade Federal de Viçosa, Instituto de Ciências Humanas no campus Florestal. Autor de: Governadores Gerais do Estado do Brasil (séculos XVI-XVII): ofício, regimentos, governação e trajetórias; Construindo o Estado do Brasil: instituições, poderes locais e poderes centrais. In: O Brasil Colonial, 14431580; Título régio, rituais e cerimônias políticas no Antigo Regime: Império e governo no ultramar luso. Revista Ultramares; O Brasil Colonial, 1580-1720.

${ }^{171}$ Entre os muitos trabalhos, citamos, como exemplo, os autores: José Ignacio Rubio Mané, Ernesto Torre Villar, Lewis Hanke e John H. Elliott. 